\title{
A new single nucleopolyhedrovirus isolate from Cabbage looper, Trichoplusia ni (Hubner) (Lepidoptera: Noctuidae): Detection, characterization and virulence
}

\author{
G. B. EROGLU ${ }^{1}$, R. NALCACIOGLU ${ }^{1}$, M. NAKAI ${ }^{2}$, Z. DEMIRBAG ${ }^{1 *}$
}

\author{
${ }^{1}$ Department of Biology, Faculty of Science, Karadeniz Technical University, Trabzon, Turkey; \\ ${ }^{2}$ Tokyo University of Agriculture and Technology, Tokyo, Japan
}

Received May 3, 2019; revised October 18, 2019; accepted September 16, 2020

\begin{abstract}
Summary. - This study was focused on the detection, characterization and virulence of a new baculovirus isolate from the larvae of cabbage looper, Trichoplusia ni (Hubner) (Lepidoptera: Noctuidae). T. ni is a polyphagous pest, and it has cosmopolitan distribution. An infected T. ni larvae was collected from a cabbage field in Turkey. Scanning electron microscopy studies showed the presence of typical occlusion bodies (OBs) with average size of 0.76 to $1.46 \mu \mathrm{m}$ in the collected larvae. Since the virions have single nucleocapsid within the envelopes, the isolate was named as Trichoplusia ni single nucleopolyhedrovirus Turkey isolate (TrniSNPV- TR). The total genome of the TrniSNPV-TR was determined as $122.9 \mathrm{~kb}$ in size. Sequence analysis of the amplified late expression factor 8 (lef8), late expression factor 9 (lef9) and polyhedrin (polh) genes showed that the virus is a new isolate of nucleopolyhedroviruses and close to Trichoplusia ni SNPV isolates mentioned in the literature. However, this is the first study for the detection and characterization of a baculovirus from $T$. $n i$ in Eurasian region. Insecticidal activities of the TrniSNPV-TR isolate $\left(10^{6} \mathrm{OBs} / \mathrm{ml}^{-1}\right)$ against neonate, $3^{\text {rd }}$ and $5^{\text {th }}$ instar larvae of $T$. ni and Helicoverpa armigera showed $98 \%-91 \%, 91 \%-87 \%$ and $65 \%-60 \%$ mortalities, respectively, within 14 days. LC $_{50}$ of TrniSNPV-TR was determined as $2 \times 10^{3}-9 \times 10^{3}, 3 \times 10^{4}-7 \times 10^{4}$ and $1 \times 10^{5}-2 \times 10^{5} \mathrm{OBs} / \mathrm{ml}$ on neonate, $3^{\text {rd }}$ and $5^{\text {th }}$ instar larvae, respectively. All these results showed that, TrniSNPV-TR has good potential to be utilized as a bio-pesticide against T. ni larvae in the future.
\end{abstract}

Keywords: baculovirus; nucleopolyhedrovirus; Trichoplusia ni; TrniSNPV-TR; biological control

\section{Introduction}

The Baculoviridae family infects arthropods, generally hexapods from the order of Lepidoptera and some others from Hymenoptera and Diptera (Blissard et al., 2000; Theilmann et al., 2005). Rod shaped particles of baculo-

"Corresponding author. E-mail: zihni@ktu.edu.tr; phone: +90462-377-33-20.

Abbreviations: NPV(s) = nucleopolyhedrovirus(es); $\operatorname{SNPV(s)~=~}$ single nucleopolyhedrovirus(es); OBs = occlusion bodies; TEM = transmission electron microscopy; $\mathrm{SEM}=$ scanning electron microscopy; $\mathrm{kDa}=$ Kilodalton; lef8 = late expression factor 8; lef9 $=$ late expression factor 9 ; polh = polyhedrin viruses contain supercoiled genomes with sizes ranging from 80 to $180 \mathrm{kbp}$ (Van Oers and Vlak, 2007; Jiang et al., 2008; Harrison, 2009). They are classified into four genera based on their host and occlusion body (OB) morphology: Alphabaculovirus, lepidopteran-specific nucleopolyhedroviruses(NPVs); Betabaculovirus, lepidopteran-specific granuloviruses (GVs); Gammabaculovirus, hymenopteranspecific NPVs; and Deltabaculovirus, dipteran-specific NPVs (Harrison and Hoover, 2012). OBs of baculoviruses are easily observed under light microscope in contrast to other viruses (Boucias and Pendland, 1998; Harrison and Hoover, 2012). Baculoviruses are the most intensively studied entomopathogenic viruses (Inceoglu et al., 2006). There are more than 30 baculovirus products in the market (Ranga et al., 2015). 
Cabbage looper [Trichoplusia ni (Hubner) (Lepidoptera: Noctuidae)] larvae cause serious economic damage in vegetable crops (Sangha et al., 2011). It feeds on broccoli, cabbage, cucumber, lettuce, potato, tomato and watermelon (Davidson and Lyon, 1999). Particularly, the third and subsequent instars of the pest consume large quantities of plant material (McEwen and Hervey, 1960). Biological control approaches against $T$. ni have focused on the effectiveness of Bacillus thuringiensis (Bt) toxins and some baculovirus isolates (Wang et al., 2007; Sarfraz et al., 2010). However, cases of insect resistance to $B t$ have been reported (Janmaat and Myers, 2003; Kain et al., 2015). On the other hand, several isolates of baculoviruses, TnSNPV and TnMNPV have been appreciated as biocontrol agents against T. ni larvae (Drake and McEven, 1959; Jaques, 1972; Jaques, 1977; Vail et al., 1999; Erlandson et al., 2007). Besides, some Authographa californica NPV isolates have also infectivity for cabbage looper larvae (Harrison and Bonning, 2003). However, it is always desired to investigate more infectious isolates that can be utilized as more effective product for agricultural purpose.

In this study, we detected a new baculovirus isolate of T. ni obtained from cabbage fields in Trabzon, Turkey. The virus was characterized by phase-contrast and electron microscopy, sodium dodecyl sulfate-polyacrylamide gel electrophoresis (SDS-PAGE) of polypeptides, the sequence of three conserved genes (lef8, lef9 and polh) and restriction endonuclease analysis of genomic DNA. Additionally, the virulence of the isolate was determined against the neonate, $3^{\text {rd }} 5^{\text {th }}$ instar larvae of T. ni and H. armigera.

\section{Materials and Methods}

Virus isolation and propagation. Trichoplusia ni larvae were collected from cabbage fields in Trabzon, Turkey. The one infected larva showed signs of baculovirus infection and subsequently died. Phase contrast microscopic observations of wet mount preparation from all infected larvae showed typical bright occlusion bodies (OB) of baculoviruses. The suspension of OBs was used for the verification of virus infection following Koch Postulates (Evans, 1976). These OBs were propagated in laboratory-reared T. ni larvae. The larvae were fed with $10^{6} \mathrm{OBs} /$ $\mathrm{ml}$ on the surface of cabbage leaf and placed in plastic dishes individually. After consuming the infected leaves, the larvae were fed with fresh leaves and continued maintaining at $28^{\circ} \mathrm{C}$. OBs were purified from infected larvae according to the procedure described by Muñoz et al. 1997.

Morphological studies. Morphological characterization of the virus isolate was performed by light and electron microscopy. The OBs were examined under phase-contrast microscope (Nikon Eclipse E600). For scanning electron microscopy (SEM), $25 \mu \mathrm{l}$ OBs were placed on a coverslip, and then, the coverslip was covered with gold (Quorum Technology SC7620-CF) (Torquato et al., 2006; Eroglu et al., 2018). The sizes of OBs were measured using SEM (Agilent Technologies). For transmission electron microscopy (TEM), OBs were prepared according to the method described by Demir et al. (2014).

SDS-PAGE analysis. Viral proteins were analyzed by sodium dodecyl sulfate-polyacrylamid gel electrophoresis (SDS-PAGE) (Laemmli, 1970). Purified OB suspension was boiled at $100^{\circ} \mathrm{C}$ for $5 \mathrm{~min}$ in loading dye and beta mercaptoethanol, loaded into wells of $12 \%$ SDS-PAGE gel and electrophoresed at $80 \mathrm{~V}$ for $3 \mathrm{~h}$. The gel was stained with Coomassie brilliant blue R-250 to visualize the protein bands (Sambrook et al., 1989).

DNA isolation and restriction endonuclease analysis. Viral DNA was isolated using Qiagen complete DNA isolation kit according to the manufacturer's instructions. Approximately $1 \mu \mathrm{g}$ DNA was digested with BamHI restriction endonuclease (Biolabs) at $37^{\circ} \mathrm{C}$ for $4 \mathrm{~h}$. The samples were electrophoresed in a $0.7 \%$ agarose gel at $14 \mathrm{~V}$ for $17 \mathrm{~h}$. HindIII and NarI digested $\lambda$ DNA (Fermentas) samples were used as molecular weight markers.

Amplification and phylogenetic analysis. The conserved partial regions of lef8, lef 9 and polh genes were amplified by polymerase chain reaction (PCR). The degenerate primer sets used for amplification are listed in Table 1. The PCR conditions were adjusted in $50 \mu \mathrm{l}$ reaction volume containing $10 \mathrm{ng}$ of viral DNA, $1 \mu \mathrm{l}$ of $10 \mathrm{mM}$ each forward and reverse primers, $0.2 \mathrm{mM}$ of dNTP, $0.25 \mu$ l of GoTaqDNA polymerase enzyme (Promega), $6 \mu \mathrm{l}$ of $25 \mathrm{mM} \mathrm{MgCl}_{2}$ and $10 \mu \mathrm{l}$ of $5 \mathrm{X}$ Green GoTaq Flexi buffer. PCR conditions were applied using the parameters recommended by the manufacturer. So, first $2 \mathrm{~min}$ incubation at $95^{\circ} \mathrm{C}$ was followed by 35 cycles of $1 \mathrm{~min}$ at $95^{\circ} \mathrm{C}, 30 \mathrm{~s}$ at $42^{\circ} \mathrm{C}$ (for polh) $/ 58^{\circ} \mathrm{C}$ (for lef 8 and lef9) and $1 \mathrm{~min}$ at $72^{\circ} \mathrm{C}$; and a final extension step

Table 1. Primer sets of baculovirus partial genes

\begin{tabular}{llcl}
\hline Primer name & Primer sequence & Tm $\left({ }^{\circ} \mathbf{C}\right)$ & Reference \\
\hline polh $\mathrm{F}$ & 5'-TAYGTGTAYGAYAACAAGT-3' & $42^{\circ} \mathrm{C}$ & de Moraes and Maruniak, 1997 \\
polh $\mathrm{R}$ & 5'-TTGTARAAGTTYTCCCAG-3' & & \\
lef8 $\mathrm{F}$ & 5'-GTAAAACGACGGCCAGTTYTTYCAYGGNGA-3' & & Herniou, 2003 \\
lef8 $\mathrm{R}$ & 5'-AACAGCTATGACCATGGNAYRTANGGRTCY-3' & & \\
lef9 $\mathrm{F}$ & 5'-CAGGAAACAGCTATGACCAARAAYGGITAYGCBG-3' & $58^{\circ} \mathrm{C}$ & Lange et al., 2004 \\
lef9 $\mathrm{R}$ & 5'-TGTAAAACGACGGCCAGTTTGTCDCCRTCRCARTC-3' & & \\
\hline
\end{tabular}


Table 2. Sequences of baculoviruses used for phylogenetic analysis

\begin{tabular}{|c|c|c|c|c|}
\hline \multirow{2}{*}{ Viral isolates } & \multirow{2}{*}{ Family } & \multicolumn{3}{|c|}{ NCBI no } \\
\hline & & lef8 & lef9 & polh \\
\hline Agrotis segetum NPV & Noctuidae & AY706535 & AY706600 & AY706683 \\
\hline Busseola fusca NPV & Noctuidae & AY519223 & AY519224 & AY519222 \\
\hline Helicoverpa armigera NPV & Noctuidae & HQ246109 & HQ246125 & HQ246082 \\
\hline Helicoverpa zea NPV & Noctuidae & HQ246103 & HQ246124 & HQ246096 \\
\hline Mythimna separata NPV & Noctuidae & AB308407 & AB308408 & AB308406 \\
\hline Spodoptera littoralis NPV & Noctuidae & AY706585 & AY706650 & AY706717 \\
\hline Spodoptera litura NPV & Noctuidae & AY706580 & AY706645 & AY706714 \\
\hline Spodoptera terricola NPV & Noctuidae & AY706582 & AY706647 & AY706716 \\
\hline Trichoplusia ni SNPV* & Noctuidae & KY356083 & KY356084 & KY356085 \\
\hline Trichoplusia ni NPV & Noctuidae & AY449798 & JN674728 & AF093405 \\
\hline Xestia c-nigrum GV & Noctuidae & AF162221 & AF162221 & AF162221 \\
\hline
\end{tabular}

“*” Indicates the current isolate.

of $5 \mathrm{~min}$ at $72^{\circ} \mathrm{C}$. The nucleotide sequences were detected by automated sequencing (Macrogen) and registered at the GenBank. The accession numbers of the sequences were obtained for lef8 (KY356083), lef9 (KY356084) and polh (KY356085) partial conserved genes. The genes used for the phylogenetic analysis, are listed in Table 2 . The phylogenetic trees were drawn with neighbor joining analysis of MEGA software (6.0.6 version).

Bioassays. Insecticidal activity of the new baculovirus isolate was tested on neonate, $3^{\text {rd }}$ and $5^{\text {th }}$ instars of T. ni and H. armigera larvae. Pure OBs were calculated by a hemocytometer and prepared as four different concentrations $\left(10^{3}\right.$ to $\left.10^{6} \mathrm{OBs} / \mathrm{ml}\right)$. These OBs were spread on $4 \mathrm{~mm}^{2}$ discs of cabbage leaves and each larva was placed on a separate disc. A total of 30 discs were used. Bioassays were applied on 30 larvae and repeated 3 times for each concentration. Tests were performed at $28^{\circ} \mathrm{C}$ and $60 \%$ humidity. The control group was fed with distilled water treated cabbage leaves. After consuming the infected leaves, all larvae were fed on fresh cabbage leaves throughout 14 days. Time mortality value was subjected to Abbott's formula (Abbott,1925) and the $\mathrm{LC}_{50}$ value using the probit analysis by SPSS ( 24 version).

\section{Results and Discussion}

\section{Morphological studies}

Phase-contrast microscopy examination of pure TrniSNPV-TR showed typical OBs of baculovirus, as light crystals (Fig. 1a). The SEM examinations showed irregular shaped OBs that ranged in size from 0.76 to $1.46 \mu \mathrm{m}$ (Fig. 1b). The OB sizes of the NPVs range from 0.4 to $5 \mu \mathrm{m}$ (Federici, 1995; Harrison and Hoover, 2012). This is the first detailed study about morphology of Trichoplusia ni NPV. The OB size of the TrniSNPV-TR isolate was close to ManeNPV $(0.87-1.75 \mu \mathrm{m})$, HearNPV $(0.85-1.25 \mu \mathrm{m})$ and EcobNPV $(0.7-1.7 \mu \mathrm{m})$ isolates but smaller than LdNPV (0.8-2.02 $\mu \mathrm{m})$, SpltNPV (0.9-2.92 $\mu \mathrm{m})$ and AmalNPV (1-2 $\mu \mathrm{m}$ ) isolates (Ma et al., 2006; Sridhar et al., 2011; Demir et al., 2013; Bayramoglu et al., 2017; Eroglu et al., 2018). TEM studies revealed that OBs have one enveloped nucleocapsid per virion (Fig. 1c). The length of nucleocapsid is $25 \mathrm{~nm}$ to $123 \mathrm{~nm}$.
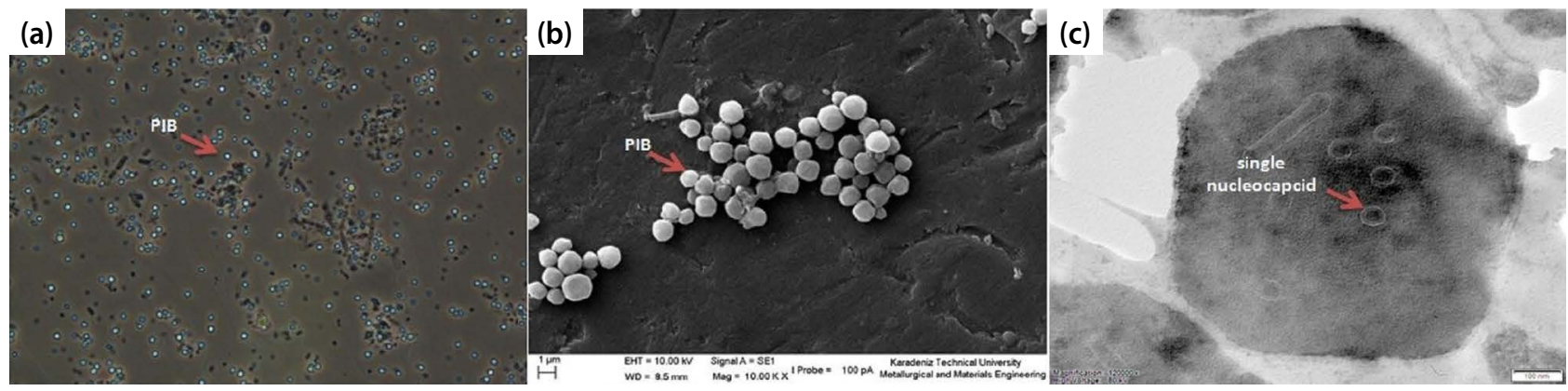

Fig. 1

The microscopic observation of Trichoplusia ni single nucleopolyhedrovirus (TrniSNPV-TR)

(a) and (b) show the bright crystal structures of occlussion bodies (OBs) with arrow, c shows the single nucleocapsid with arrow. (a) Phase-contrast microscopy (bright field-100 $\times$ ), (b) Scanning electron micrograph of purified OBs $($ bar $=1 \mu \mathrm{m})$, (c) Transmission electron micrograph of virions ( $\mathrm{bar}=100 \mathrm{~nm}$ ). 


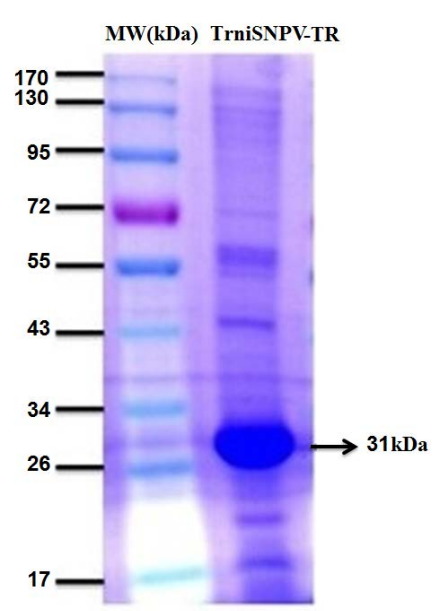

Fig. 2

SDS-PAGE analysis of viral polypeptides and polyhedrin protein of viral isolate

Total viral proteins were loaded into well of $12 \%$ SDS-polyacrylamide gel and stained with Coomassie brillent blue. MW: Molecular weight standard. Arrow shows the polyhedron protein.

\section{SDS-PAGE analysis}

Proteins of TrniSNPV-TR were determined by $12 \%$ SDS-PAGE (Fig. 2). SDS-PAGE analysis of the purified TrniSNPV-TR showed a banding pattern characteristic for baculoviruses. Polyhedrin protein, the highest expressed viral protein and a typical marker for baculoviruses, was detected on the gel with the estimated molecular weight of $31 \mathrm{kDa}$. It is one of the most conserved baculovirus proteins, polyhedrin from several viruses was characterized and was found to contain about $250 \mathrm{aa}(30 \mathrm{kDa})$ (Rohrmann, 2013). Therefore, the intense band between the 26 and $34 \mathrm{kDa}$ molecular weight markers is considered to be polyhedrin protein.

\section{Restriction endonuclease analysis}

Restriction endonuclease analysis is a significant method for comparing the molecular differences among geographical isolates (Murillo et al., 2001). The viral DNA genome was digested by BamHI enzyme. The genome of TrniSNPV-TR digested with BamHI produced 12 fragments (Fig. 3). The fragments are named alphabetically starting from $A$. The sizes of fragments were determined as $21.0,20.9,14.0,13.9,13.2,13.0,11.7,7.0,3.2,2.5,1.4$ and $1.1 \mathrm{~kb}$, respectively (Table 3 ). Based on the sizes of all fragments, the viral genome was estimated to be $122.9 \mathrm{~kb}$. The restriction endonuclease profile of the TrniSNPV-TR isolate was compared to BamHI profile of TnSNPV isolate in literature (Davis and Wood,1996). Genome sizes of both isolates are

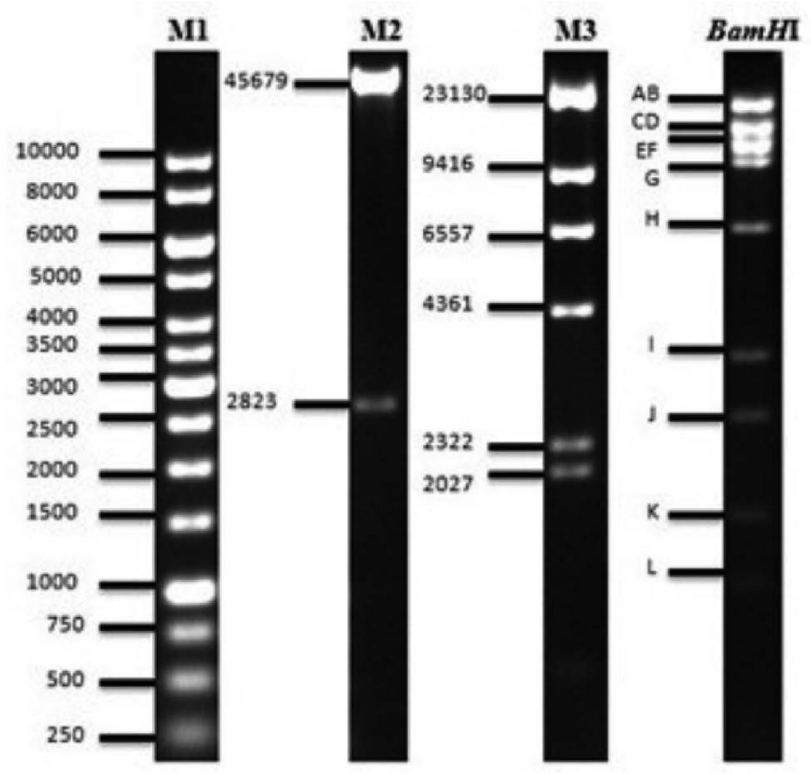

Fig. 3

Restriction fragmentation patterns of viral genomic DNA using the BamHI restriction endonuclease

Restriction fragments were separated on a $1 \%$ agarose gel at $14 \mathrm{~V}$. The letters (A-L) to the right of both lines indicate the fragments generated by restriction enzyme. M1: $1 \mathrm{~kb}$ Marker (bp); M2: $\lambda$ DNA/ HindIII; M3: $\lambda$ DNA/NarI.

similar, however there are differences in the sizes of four fragments (Fragments A, I, J and L). Willis et al. (2005) reported that whole genome sequence of TnSNPV from Canada was $134.394 \mathrm{kbp}$ in size, larger than our isolate. These differences suggest that TrniSNPV-TR isolate was a genetically distinct from TnSNPV.

Table 3. Size of TrniSNPV-TR DNA fragments generated after $B a m H I$ restriction enzyme digestion

\begin{tabular}{|c|c|}
\hline \multicolumn{2}{|c|}{ BamHI } \\
\hline Fragment & $\mathbf{K b}$ \\
\hline A & 21.0 \\
\hline B & 20.9 \\
\hline C & 14.0 \\
\hline D & 13.9 \\
\hline E & 13.2 \\
\hline $\mathrm{F}$ & 13.0 \\
\hline G & 11.7 \\
\hline $\mathrm{H}$ & 7.0 \\
\hline I & 3.2 \\
\hline $\mathrm{J}$ & 2.5 \\
\hline $\mathrm{K}$ & 1.4 \\
\hline $\mathrm{L}$ & 1.1 \\
\hline Total & 122.9 \\
\hline
\end{tabular}


(a)

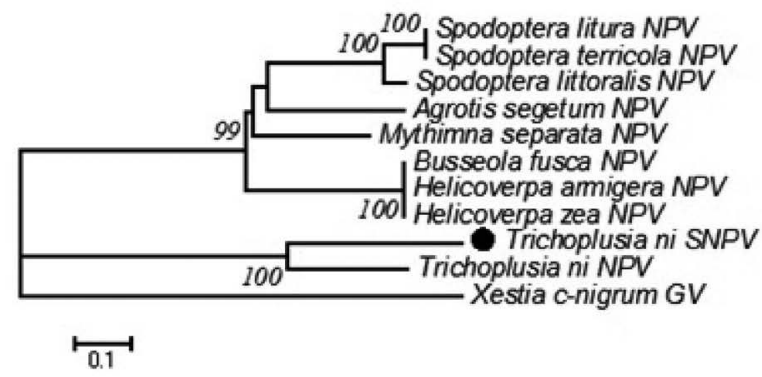

(b)

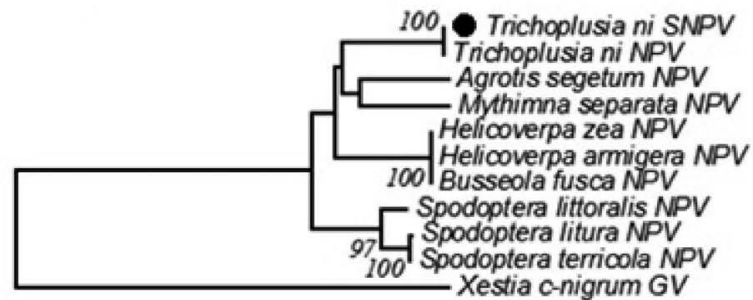

$\stackrel{\longmapsto}{0.1}$

(c)

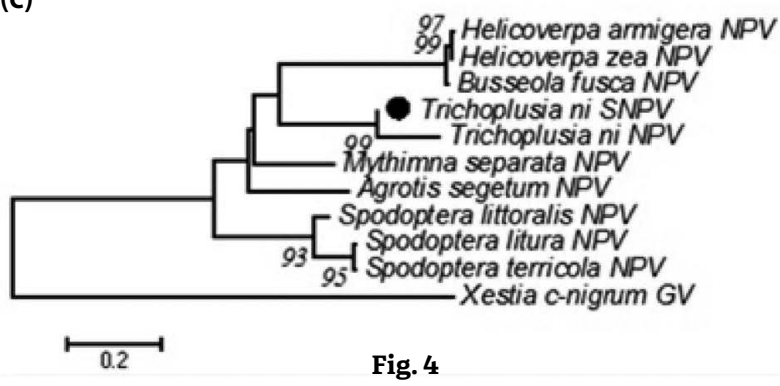

Phylogenetic analysis of TrniSNPV-TR isolate Neighbor joining trees based on partial sequences of (a) lef8, (b) lef9 and (c) polh genes. The numbers indicate bootstrap scores.

\section{Phylogenetic analysis}

Three conserved baculovirus genes (lef8, lef9 and polh) were amplified by PCR. The amplified fragments of lef8, lef9 and polh genes, at $408 \mathrm{bp}, 197 \mathrm{bp}$ and $401 \mathrm{bp}$ in sizes, respectively, were sequenced. The partial sequences were compared to sequences of known nucleopolyhedrovirus existing in NCBI database. Results showed that TrniSNPVTR clustered together with England, California and South Africa TnSNPV isolates listed in GenBank (Fig. 4a,b,c).

\section{Bioassays}

The highest mortality rate was detected following infection with $10^{6} \mathrm{OBs} / \mathrm{ml}$ within 14 days. TrniSNPV-TR caused $98 \%-91 \%, 91 \%-87 \%$ and $65 \%-60 \%$ mortalities, increasing with growing virus concentration (up to $10^{6} \mathrm{OBs}$ / $\mathrm{ml}^{-1}$ ), on neonate, $3^{\text {rd }}$ and $5^{\text {th }}$ instar larvae of both insects (Fig. 5a,b). The $\mathrm{LC}_{50}$ mortality rates of TrniSNPV-TR on neonate, $3^{\text {rd }}$ and $5^{\text {th }}$ instar larvae of T. ni attained $2 \times 10^{3}, 3 \times 10^{4}$ and $1 \times 10^{5} \mathrm{OBs} / \mathrm{mL}$, respectively, and that of $H$. armigera $9 \times 10^{3}, 7 \times 10^{4}, 2 \times 10^{5} \mathrm{OBs} / \mathrm{mL}$, respectively (Table 4). Fuxa et al. (2002) declared $\mathrm{LC}_{50}$ values of $4.8 \times 10^{4} \mathrm{OBs} / \mathrm{ml}$ for $5^{\text {th }}$ instar larvae of T. ni. Harrison et al. (2012) reported that different isolates of TnSNPV - TnSNPV-230, 246, 455 from USA had a $\mathrm{LC}_{50}$ values of $2.5 \times 10^{6}, 1.4 \times 10^{6}$ and $8.7 \times 10^{5} \mathrm{OBs} /$ $\mathrm{ml}$ for neonate, respectively.

\section{Conclusion}

In this study we detected a TrniSNPV-TR isolate from Eurasia region for the first time. To be able to use the viral isolate as a microbial pesticide, the molecular and pathogenic properties of the virus need to be identified. Therefore, in this study we characterized the viral isolate and

Table 4. Probit regression values for TrniSNPV-TR isolate against neonate, $3^{\text {rd }}$ and $5^{\text {th }}$ instars larvae of $T$. ni and $H$. armigera for 14 days

\begin{tabular}{lcccccc}
\hline Bioassay & Intercept & Slope \pm SE & Mortality rate & LC $_{\mathbf{5 0}}(\mathbf{F L}, \mathbf{9 5} \%)$ & $\chi^{\mathbf{2}}$ & $\mathbf{d f}$ \\
\hline T. ni neonate & $-2,3 \pm 0,3$ & $0,50 \pm 0,08$ & $98 \%$ & $2 \times 10^{3}$ & 2,1 & 3 \\
T. ni $3^{\text {rd }}$ instar & $-1,7 \pm 0,3$ & $0,55 \pm 0,06$ & $91 \%$ & $3 \times 10^{4}$ & 1,8 & 3 \\
T. ni $5^{\text {th }}$ instar & $-1,8 \pm 0,3$ & $0,45 \pm 0,06$ & $65 \%$ & $1 \times 10^{5}$ & 2,7 & 3 \\
H. armigera neonate $^{\text {r }}$ & $-1,9 \pm 0,2$ & $0,60 \pm 0,06$ & $91 \%$ & $9 \times 10^{3}$ & 2,8 & 3 \\
Hrmigera $3^{\text {rd }}$ instar & $-1,6 \pm 0,3$ & $0,65 \pm 0,06$ & $87 \%$ & $7 \times 10^{4}$ & 2,7 & 3 \\
H. armigera $^{\text {th }}$ instar & $-1,8 \pm 0,3$ & $0,43 \pm 0,06$ & $60 \%$ & $2 \times 10^{5}$ & 3,4 & 3 \\
\hline
\end{tabular}

SE: Standard error, FL: Fiducial limit, $\chi^{2}$ : Chi square, df: Degree of freedom. 
(a)
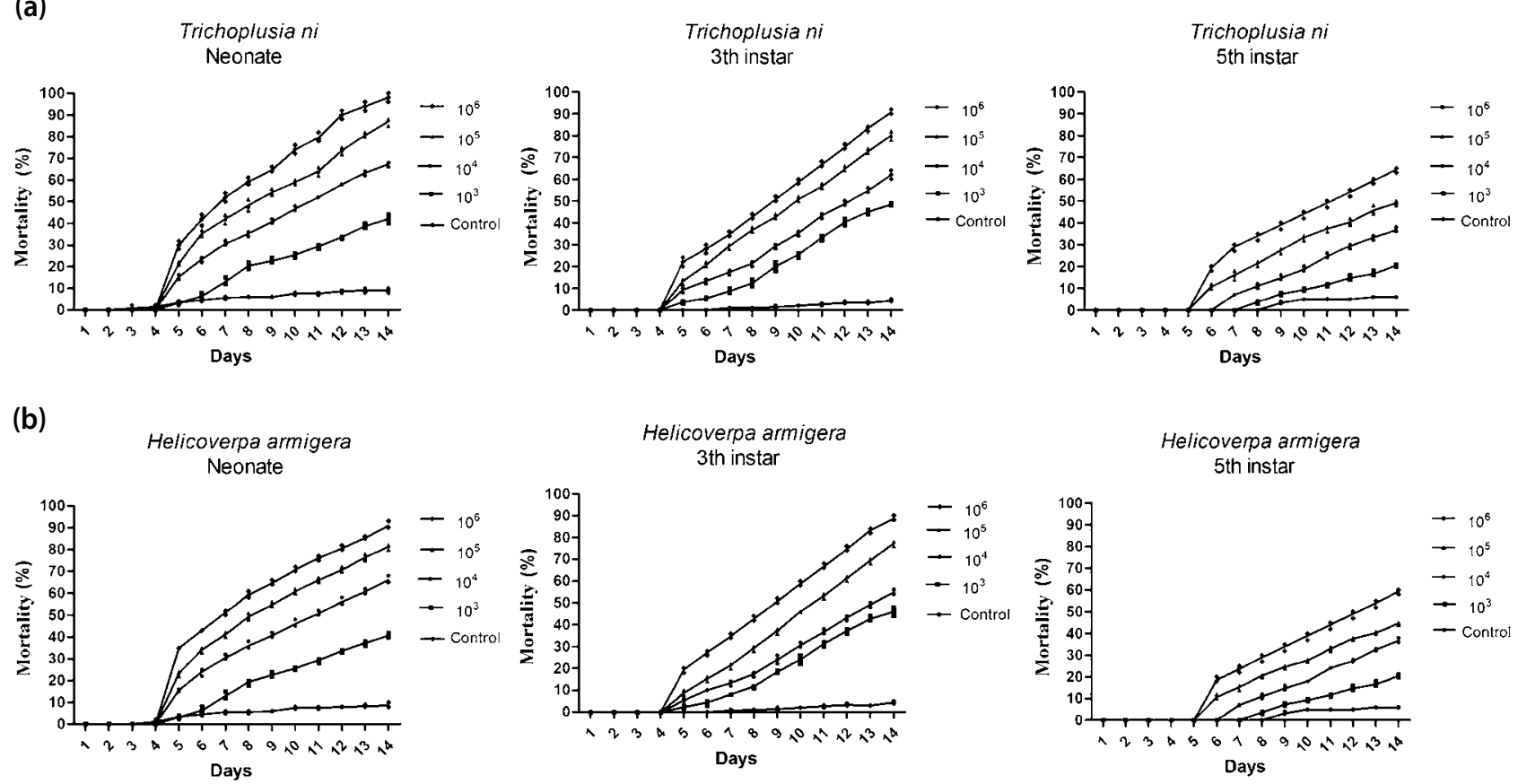

Fig. 5

Insecticidal activity of the viral isolate against neonate, $3^{\text {rd }}$ and $5^{\text {th }}$ instar larvae

(a) T. ni and (b) H. armigera, respectively. Results were evaluated at 14 days post inoculations.

defined the virulence on T.ni and H. armigera. Our results indicated that there are significant differences in terms of virulence and host range between the TrniSNPV-TR and the previous isolates. In conclusion, current results show that TrniSNPV-TR can be used as microbial control agent to be utilized as effective bio pesticide to control populations of T. ni and H. armigera.

Acknowledgments. We would like to thank to Prof. Aykut CANAKCI from Department of Metallurgical and Materials Engineering, Karadeniz Technical University (Trabzon, Turkey) for assistance with scanning electron microcopy studies. This study was financially supported by Karadeniz Technical University (Project No: BAP01 FBA-2018-6800).

\section{References}

Abbott WS (1925): A method of computing the effectiveness of an insecticide. J. Econ. Entomol. 18, 265-267. https:// doi.org/10.1093/jee/18.2.265a

Bayramoglu Z, Gencer D, Muratoglu H, Efe D, Nalcacioglu R, Demirbag Z, Demir I (2017): Characterization of a nucleopolyhedrovirus variant of the gypsy moth, Lymantria dispar (Lepidoptera: Lymantriidae) in Turkey. Int. J. Pest Manag. 64, 119-127. https://doi.org/10.1080/096 $\underline{70874.2017 .1344789}$
Blissard GW, Black B, Crook N, Keddie BA, Possee R, Rohrmann G, Theilmann DA, Volkman L (2000): Family Baculoviridae. Virus Taxonomy, Seventh Report of the International Committee on the Taxonomy of Viruses. Elsevier, Oxford, pp. 195-202

Boucias DG, Pendland JC (1998): Principles of Insect Pathology. Kluwer Academic Publishers, Boston. https://doi. org/10.1007/978-1-4615-4915-4

Davidson RH, Lyon WF (1999): Insect Pests of Farm, Garden and Orchard. John Wiley \& Sons Inc, USA.

Davis TR, Wood HA (1996): In vitro characterization of a Trichoplusia ni single nucleocapsid nuclear polyhedrosis virus. J. Gen. Virol. 77, 2303-2310. https://doi. org/10.1099/0022-1317-77-9-2303

De Moraes RR, Maruniak JE (1997): Detection and identification of multiple baculoviruses using the polymerase chain reaction (PCR) and restriction endonuclease analysis. J. Virol. Methods 63, 209-217. https://doi.org/10.1016/ S0166-0934(96)02130-1

Demir I, Nalcacioglu R, Mohammad Gholizad L, Demirbag Z (2013): Characterization of a new isolate of Malacosoma neustria nucleopolyhedrovirus (ManeNPV) from Turkey. Turk. J. Biol. 37, 385-391. https://doi. org/10.3906/biy-1209-24

Demir I, Nalcacioglu R, Mohammed Gholizad L, Demirbag Z (2014): A highly effective nucleopolyhedrovirus against Malacosoma spp.(Lepidoptera: Lasiocampidae) from Turkey: isolation, characterization, phylogeny, and 
virulence. Turk. J. Agric. For. 38, 462-470. https://doi. org/10.3906/tar-1307-32

Drake EL, McEven FL (1959): Pathology of a nucleopolyhedrosis of the cabbage looper Trichoplusia ni (Hubner). J. Insect Pathol. 1, 281-293.

Erlandson M, Newhouse S, Moore K, Janmaat A, Myers J, Theilmann D (2007): Characterization of baculovirus isolates from Trichoplusia ni populations from vegetable greenhouses. Biol. Control 41, 256-263. https:// doi.org/10.1016/j.biocontrol.2007.01.011

Eroglu GB, Demir I, Demirbag Z (2018): A novel alphabaculovirus isolated from the cotton bollworm, Helicoverpa armigera (Hubner) (Lepidoptera: Noctuidae): Characterization and pathogenicity. Biologia 73, 545-551. https:// doi.org/10.2478/s11756-018-0053-2

Evans AS (1976): Causation and disease: the Henle-Koch postulates revisited. Yale J. Biol. Med. 49, 175-195.

Federici B (1995): Baculovirus pathogenesis. In Miller LK (Ed.): The Baculoviruses. Plenum Press, pp. 33-59. https:// doi.org/10.1007/978-1-4899-1834-5 3

Fuxa JR, Richter AR, Ameen AO, Hammock BD (2002): Vertical transmission of TnSNPV, TnCPV, AcMNPV, and possibly recombinant NPV in Trichoplusia ni. J. Invertebr. Pathol. 79, 44-50. https://doi.org/10.1016/ S0022-2011(02)00003-4

Harrison RL, Bonning BC (2003) Comparative analysis of the genomes of Rachiplusia ou and Autographa californica multiple nucleopolyhedroviruses. J. Gen. Virol. 84, 1827-1842. https://doi.org/10.1099/vir.0.19146-0

Harrison RL (2009): Structural divergence among genomes of closely related baculoviruses and its implications for baculovirus evolution. J. Invertebr. Pathol.101,181-186. https://doi.org/10.1016/i.jip.2009.03.012

Harrison RL, Hoover K (2012): Baculoviruses and other occluded insect viruses. In Vega FE, Kaya HK (Eds.): Insect Pathology. Academic Press, pp. 73-132. https://doi. org/10.1016/B978-0-12-384984-7.00004-X

Harrison RL, Popham HJ, Breitenbach JE, Rowley DL (2012): Genetic variation and virulence of Autographa californica multiple nucleopolyhedrovirus and Trichoplusia ni single nucleopolyhedrovirus isolates. J. Invertebr. Pathol. 110, 33-47. https://doi.org/10.1016/j. jip.2012.02.002

Herniou EA (2003): Use of Comparative Genomics and Phylogenetics to study the Evolution of the Baculoviridae. $\mathrm{PhD}$ Thesis, Department of Biological Sciences, Imperial College, London, 84.

Inceoglu AB, Kamita SG, Hammock BD (2006): Genetically Modified Baculoviruses: A Historical Overview and Future Outlook. Adv. Virus Res. 68, 323-360. https:// doi.org/10.1016/S0065-3527(06)68009-3

Jaques RP (1972): Control of the cabbage looper and imported cabbageworm by viruses and bacteria. J. Econ. Entomol. 65, 757-760. https://doi.org/10.1093/jee/65.3.757

Jaques RP (1977): Field efficacy of viruses infectious to the cabbage looper and imported cabbage worm on late cabbage. J. Econ. Entomol. 70, 111-118. https://doi. org/10.1093/jee/70.1.111
Janmaat AF, Myers J (2003): Rapid evolution and the cost of resistance to Bacillus thuringiensis in greenhouse populations of cabbage loopers, Trichoplusia ni. Proc. Biol. Sci. 270, 2263-2270. https://doi.org/10.1098/ rspb.2003.2497

Jiang Y, Deng F, Wang H, Hu Z (2008): An extensive analysis on the global codon usage pattern of baculoviruses. Arch. Virol. 153, 2273-2282. https://doi.org/10.1007/ s00705-008-0260-1

Kain W, Song X, Janmaat AF, Zhao JZ, Myers J, Shelton, AM, Wang P (2015): Resistance of Trichoplusia ni populations selected by Bacillus thuringiensis sprays to cotton plants expressing pyramided Bacillus thuringiensis toxins Cry1Ac and Cry2Ab. Appl. Environ. Microbiol. 81, 1884-1890. https://doi.org/10.1128/AEM.03382-14

Laemmli UK (1970): Cleavage of structural proteins during the assembly of the head of bacteriophage T4. Nature 227, 680-685. https://doi.org/10.1038/227680a0

Lange M, Wang H, Zhihong H, Jehle JA (2004): Towards a molecular identification and classification system of lepidopteran-specific baculoviruses. Virology 325 36-47. https://doi.org/10.1016/j.virol.2004.04.023

Ma XC, Xu HJ, Tang MJ, Xiao Q, Hong J, Zhang CX (2006): Morphological, phylogenetic and biological characteristics of Ectropis obliqua single-nucleocapsid nucleopolyhedrovirus. J. Microbiol. 44, 77-82.

McEwen FL, Hervey GER (1960): Mass-rearing the cabbage looper, Trichoplusia ni, with notes on its biology in the laboratory. Ann. Entomol. Soc. Am. 53, 229-234. https://doi.org/10.1093/aesa/53.2.229

Muñoz D, Vlak JM, Cabellero P (1997): In vivo recombination between two strains of the genus nucleopolyhedrovirus in its natural host, Spodoptera exigua. Appl. Environ. Microbiol. 63, 3025-3031 https://doi.org/10.1128/ AEM.63.8.3025-3031.1997

Murillo J, Muñoz D, Lipa JJ, Cabellero P (2001): Biochemical characterization of three nucleopolyhedrovirus isolates of Spodoptera exigua and Mamestra brassicae. J.Appl. Entomol.125, 267-270.https://doi.org/10.1046/ j.1439-0418.2001.00533.x

Ranga Rao GV, Sridhar Kumar CH, Sireesha K, Lava Kumar P (2015): Role of Nucleopolyhedroviruses (NPVs) in the Management of Lepidopteran Pests in Asia. In Sree KS, Varma A (Eds.): Biocontrol of Lepidopteran Pests. The series Soil Biology, pp. 11-52. https://doi. org/10.1007/978-3-319-14499-3 2

Rohrmann GF (2013): Structural proteins of baculovirus occlusion bodies and virions. In Baculovirus Molecular Biology. National Center for Biotechnology, Bethesda, MD, USA.

Sambrook J, Fritsch EF, Maniatis T (1989): Molecular Clonning. 2nd ed. Cold Spring Habor Laboratory Press, New York.

Sangha JS, Khan W, Ji X, Zhang J, Mills AAS, Critchley AT (2011): Carrageenans, sulphated polysaccharides of red seaweeds, differentially affect Arabidopsis thaliana resistance to Trichoplusia ni (Cabbage looper). Plos One 6 , e26834. https://doi.org/10.1371/journal.pone.0026834 
Sarfraz RM, Cervantes V, Myers JH (2010): Resistance to Bacillus thuringiensis in the cabbage looper (Trichoplusia ni) increases susceptibility to a nucleopolyhedrovirus. J. Invertebr. Pathol. 105, 204-206. https://doi. org/10.1016/j.jip.2010.06.009

Sridhar KCh, Ranga GV, Lava Kumar P (2011): Isolation and characterization of baculoviruses from three major Lepidopteran pests in the semi-arid tropics of India. Indian J.Virol.22,29-36.https://doi.org/10.1007/s13337011-0029-0

Theilmann DA, Blissard GW, Bonning B, Jehle J, O'Reilly DR, Rohrmann GF, Thiem S, Vlak JM (2005): Family Baculoviridae. In Fauguet CM, Mayo MA, Maniloff J, Desselberger U, Ball LA (Eds.): Virus Taxonomy. VIII Report of the International Committee on Taxonomy of Viruses. Elsevier, London, pp. 177-185.

Torquato EF, de Miranda Neto MH, Brancalhão RM, Franco VS (2006): Nucleopolyhedrovirus: Scanning electron microscopy technique. Neotrop. Entomol. 35, 787-790. https://doi.org/10.1590/S1519-566X2006000600011
Wang P, Zhao JZ, Rodrigo-Simon A, Kain W, Janmaat AF, Shelton AM, Ferré J, Myers J (2007): Mechanism of resistance to Bacillus thuringiensis toxin CrylAc in a Greenhouse population of the cabbage looper, Trichoplusia ni. Appl. Environ. Microbiol. 73, 1199e1207. https://doi. org/10.1128/AEM.01834-06

Vail P, Hostetter DL, Hoffman DL (1999): Development of the multinucleopolyhedroviruses (MNPVs) infectious to loopers (Lepidoptera: Noctuidae: Plusiinae) as microbial control agents. Integrated Pest Management Reviews 4, 231-257. https://doi.org/10.1023/ A:1009601212375

Van Oers MM, Vlak JM (2007): Baculovirus genomics. Curr. Drug Targets 8, 1051-1068. https://doi.org/10.2174/ $\underline{138945007782151333}$

Willis LG, Seipp R, Stewart TM, Erlandson MA, Theilmann DA (2005): Sequence analysis of the complete genome of Trichoplusia ni single nucleopolyhedrovirus and the identification of a baculovirus photolyase gene. Virology 338, 209-226. https://doi.org/10.1016/i.virol.2005.04.041 